\title{
THE EFFECT OF PROFITABILITY, LIQUIDITY, GROWTH SALES, OPERATING LEVERAGE AND TANGIBILITY ON CAPITAL STRUCTURE (evidence from manufacture firm listed on Indonesia stock exchange in 2011- 2014)
}

\author{
Hamidah \\ Faculty of Economic State University of Jakarta \\ Email: hamidahsam@gmail.com \\ Diana Iswara \\ Management Faculty Of Economic State University Of Jakarta \\ Email: dianaa.iswaraa@gmail.com \\ Umi Mardiyati \\ Faculty of Economic State University of Jakarta \\ Email: umi.mardiyati@gmail.com
}

\begin{abstract}
The purpose of this study is to know the effect of profitability, liquidity, sales growth, operating leverage and tangibility on capital structure: evidence from manufacture firm listed on Indonesia Stock Exchange in 2011-2014. The sample using in this study is 41 companies. The research model in this study employs panel data analysis (unbalanced panel) with fixed effect approach. The result show that profitability and liquidity have negative and significant effect on capital structure. Sales growth and operating leverage have positive but not significant effect on capital structure. Tangibility have negative and not significant effect on capital structure.
\end{abstract}

Key words: Profitability, liquidity, sales growth, operating leverage, tangibility, capital structure, manufacture firm 


\section{PENDAHULUAN}

Dalam perkembangan era globalisasi modern saat ini, tantangan yang harus dihadapi oleh perusahaan akan semakin berat dalam peta persaingan perekonomian yang sangat tinggi. Tidak hanya bertujuan untuk dapat survive melainkan harus mampu memiliki keunggulan bersaing dibandingkan dengan perusahaan lain. Perusahaan harus dapat lebih unggul dalam bersaing baik menghadapi pesaing perusahaan yang berasal dari dalam negeri maupun perusahaan-perusahaan asing yang memiliki modal yang melimpah. Kemajuan perekonomian Indonesia yang berkembang begitu pesat membuat perusahaan yang ada dituntut untuk melakukan ekspansi demi menjaga persaingan dan terus mengembangkan bisnis yang dijalankannya.

Persaingan yang ketat antar perusahaan juga membuat perusahaan khususnya perusahaan manufaktur untuk melakukan kegiatan ekonomi dan mengelola fungsi-fungsi yang terdapat di dalam perusahaan secara efektif. Dalam hal ini manajemen keuangan memiliki tanggungjawab untuk menciptakan dan menjaga nilai ekonomis atau kekayaan perusahaan. Oleh karena itu dalam mengambil keputusan, manajemen keuangan harus mengingat bahwa perusahaan memiliki tujuan yaitu untuk memaksimalkan kekayaan dan memaksimalkan nilai perusahaan. Sehingga dalam melakukan kegiatan ekonomi tujuan untuk memaksimalkan laba, memakmurkan pemilik perusahaan atau pemegang saham serta mempertahankan kelangsungan hidup perusahaan dan mengembangkan usahanya dapat tercapai. Kebijakan perusahaan untuk mencapai tujuan perusahaan tersebut tidak lepas dari permasalahan seberapa besar kekuatan perusahaan dalam memenuhi kebutuhan pendanaan atau permodalannya. Sumber pendanaan atau permodalan perusahaan dapat dibedakan menjadi dua yaitu sumber dana perusahaan internal dan sumber dana perusahaan eksternal. Sumber dana internal diperoleh dari hasil kegiatan operasi perusahaan, yang terdiri dari laba ditahan dan depresiasi. Sedangkan sumber dana eksternal diperoleh dari luar perusahan, yaitu modal sendiri dan utang (pinjaman).

Agar kegiatan usaha suatu perusahaan dapat berjalan dengan lancar bahkan dapat berkembang, maka diperlukan biaya yang biasa disebut dengan modal. Modal adalah suatu hal yang sangat penting bagi sebuah perusahaan karena modal digunakan untuk membiayai operasi juga mengembangkan bisnis. Modal dapat berasal dari modal sendiri maupun dari pinjaman atau utang. Oleh karena itu menentukan struktur modal yang optimal juga penting, terlebih bagi perusahaan yang sudah go public di pasar modal. Dalam penyajian laporan keuangan bagi pihak luar, struktur modal akan mempengaruhi nilai perusahaaan tersebut. Sampai saat ini, struktur modal merupakan masalah bagi 
perusahaan karena dapat mempengaruhi nilai perusahaan. Oleh karena itu, perusahaan membutuhkan manajer keuangan untuk menciptakan struktur modal optimal yang dapat menyeimbangkan penggunaan utang dengan modal sendiri. Menurut Brigham dan Houston (2014: 171), struktur modal yang optimal merupakan struktur yang akan memaksimalkan harga saham perusahaan, dan struktur ini pada umumnya meminta rasio hutang yang lebih rendah daripada rasio yang memaksimalkan EPS yang diharapkan.

Terdapat banyak teori mengenai bagaimana struktur modal yang optimal, akan tetapi masing-masing dari teori tersebut memiliki kelebihan dan kekurangan. Penentuan struktur modal bagi perusahaan sedikit banyak akan dipengaruhi oleh faktor-faktor internal perusahaan. Beberapa dari faktor internal tersebut di antaranya profitabilitas, pembayaran dividen, ukuran perusahaan, stabilitas penjualan, struktur aktiva, operating leverage, tingkat pertumbuhan, pengendalian, dan sikap manajemen. Pada umumnya, perusahaan yang besar memiliki profitabilitas yang tinggi, stabilitas penjualan yang bagus, atau tingkat pertumbuhan tinggi cenderung akan memakai hutang dengan proporsi lebih banyak karena perusahaan tersebut lebih mudah untuk mendapatkan pinjaman dari kreditur. Akan tetapi, sebenarnya perusahaan tidak terlalu banyak membutuhkan dana dari pihak luar karena memiliki sumber dana dari dalam yaitu berupa laba yang cukup banyak.

Keputusan pendanaan atau struktur modal yang tidak cermat akan berpengaruh langsung terhadap penurunan profitabilitas perusahaan tersebut. Keputusan struktur modal yang diambil oleh manajer keuangan tidak hanya berpengaruh terhadap profitabilitas perusahaan, tetapi keputusan pendanaan atau struktur modal secara langsung dapat berpengaruh terhadap besarnya risiko yang ditanggung pemegang saham serta besarnya tingkat pengembalian atau tingkat keuntungan yang diharapkan (Brigham dan Houston, 2014: 155).

Saat ini dunia usaha sangat tergantung pada masalah pendanaan. Dunia usaha mengalami kemunduran yang diakibatkan oleh banyaknya lembaga-lembaga keuangan yang mengalami kesulitan keuangan sebagai akibat adanya kemacetan kredit pada dunia usaha tanpa memperhitungkan batas maksimum pemberian kredit dimasa lalu oleh perbankan dan masalah kelayakan kredit yang disetujui. Untuk mengantisipasi hal tersebut, maka manajer keuangan perusahaan harus lebih berhati-hati dalam menentukan struktur modal yang diharapkan perusahaan dapat meningkatkan nilai perusahaan dan lebih unggul dalam menghadapi persaingan dalam dunia bisnis saat ini. Tujuan semua 
perusahaan dalam jangka panjang adalah mengoptimalkan nilai perusahaan dan meminimalisir biaya modal perusahaan. Semakin tinggi nilai perusahaaan menggambarkan semakin sejahtera pemilik perusahaan.

Brigham dan Houston (2014: 188) mengatakan bahwa perusahaan dengan penjualan yang relatif stabil dapat lebih aman memperoleh lebih banyak pinjaman dan menanggung beban tetap yang lebih tinggi dibandingkan dengan perusahaan yang penjualannya tidak stabil. Hal tersebut harus didukung dengan modal yang cukup untuk memenuhi kebutuhan perusahaan agar dapat meningkatkan penjualan perusahaan. Perusahaan yang berkembang pesat kemungkinan akan memilih untuk menggunakan dana eksternal (hutang) sebagai pemenuhan modalnya dibandingkan dengan perusahaan yang pertumbuhan penjualannya rendah.

Penelitian mengenai faktor-faktor yang mempengaruhi struktur modal telah dilakukan. Namun dari beberapa peneliti terdahulu terdapat ketidakkonsistenan hasil penelitian. Hasil penelitian tentang faktor-faktor yang mempengaruhi struktur modal antara lain dilakukan oleh Firnanti (2011) yang meneliti pengaruh ukuran perusahaan, profitabilitas, risiko bisnis, time interest earned, dan pertumbuhan aktiva terhadap struktur modal, kemudian menyimpulkan bahwa variabel ukuran perusahaan dan risiko bisnis tidak mempunyai pengaruh signifikan, variabel profitabilitas mempunyai pengaruh negatif signifikan, sedangkan variabel time interest earned dan pertumbuhan aktiva mempunyai pengaruh positif signifikan. Hal ini berbeda dengan hasil penelitian Hestuningrum dan Darsono (2012), dimana hasil penelitian adalah variabel profitabilitas, likuiditas, dan struktur aktiva mempunyai pengaruh negatif signifikan, variabel ukuran perusahaan dan pertumbuhan perusahaan mempunyai pengaruh positif signifikan, sedangkan variabel price earning ratio tidak ditemukan pengaruh yang signifikan. Yuliati (2011) meneliti Pengujian Pecking Order Theory : Analisis FaktorFaktor Yang Mempengaruhi Struktur Modal Industri Manufaktur Di BEI Periode Setelah Krisis Moneter dan hasil penelitian adalah profitabilitas berpengaruh negatif signifikan terhadap rasio leverage untuk periode sebelum dan setelah krisis, likuiditas mempunyai pengaruh negatif signifikan terhadap rasio leverage pada periode sebelum dan setelah krisis, ukuran perusahaan berpengaruh positif signifikan terhadap rasio leverage untuk periode sebelum dan setelah krisis, dan variabel struktur aktiva, pertumbuhan perusahaan dan risiko bisnis tidak mempunyai pengaruh signifikan terhadap rasio leverage perusahaan baik pada periode sebelum maupun setelah krisis. Liwang (2011) meneliti pengaruh pertumbuhan penjualan, struktur aktiva, rasio hutang, profitabilitas, ukuran 
perusahaan, dan likuiditas terhadap struktur modal. Hasil penelitian adalah variabel pertumbuhan penjualan (GS) secara negatif dan tidak berpengaruh secara signifikan terhadap struktur modal. struktur aktiva (TA) berpengaruh secara positif terhadap struktur modal. Rasio hutang (DAR) berpengaruh secara positif dan signifikan terhadap struktur modal. Profitabilitas berpengaruh secara negatif terhadap struktur modal. Ukuran perusahaan (SIZE) secara negatif dan tidak berpengaruh secara signifikan terhadap struktur modal. likuiditas (CR) berpengaruh secara positif terhadap struktur modal. Priyono (2011) meneliti dengan judul Faktor-Faktor Yang Mempengaruhi Struktur Modal Pada Perusahaan Manufaktur Yang Terdaftar Di BEI. Penelitian ini bertujuan untuk menganalisis struktur aktiva/structure of active (SA), ukuran perusahaan/firmsize (FS), operating leverage (OL), profitabilitas (PR), likuiditas (LQ), pertumbuhan penjualan/growth of sales (GS). Hasil penelitian adalah struktur aktiva mempunyai pengaruh positif dan signifikan terhadap struktur modal. firm size tidak berpengaruh terhadap struktur modal. operating leverage tidak berpengaruh terhadap struktur modal. Profitabilitas mempunyai pengaruh negatif dan signifikan terhadap struktur modal. Likuiditas mempunyai pengaruh negatif dan signifikan terhadap struktur modal. pertumbuhan penjualan tidak pengaruh terhadap struktur modal. Kemudian, Setiana (2012) melakukan penelitian dengan judul Analisis Faktor-Faktor Yang Mempengaruhi Struktur Modal Pada Perusahaan Manufaktur Yang Listing Di Bursa Efek Indonesia (BEI) menganalisis ukuran perusahaan, pertumbuhan aset, dan profitabilitas. Hasil penelitian adalah variabel ukuran perusahaan berpengaruh negatif signifikan secara statistik terhadap struktur modal perusahaan manufaktur yang listing di Bursa Efek Indonesia (BEI). Sedangkan variabel pertumbuhan aset dan profitabilitas memiliki hubungan yang positif signifikan secara statistik terhadap struktur modal perusahaan manufaktur yang listing di Bursa Efek Indonesia (BEI). Setiyawan (2014) menganalisis pengaruh dividen, profitabilitas, ukuran perusahaan, risiko bisnis dan pajak terhadap struktur modal. Hasil penelitian adalah dividen berpengaruh positif dan signifikan terhadap struktur modal pada perusahaan sektor industri barang konsumsi, property dan real estate. Profitabilitas berpengaruh negatif dan signifikan terhadap struktur modal pada perusahaan sektor industri barang konsumsi, property dan real estate. Ukuran perusahaan dan risiko bisnis tidak berpengaruh positif dan signifikan terhadap struktur modal pada perusahaan sektor industri barang konsumsi, property dan real estate. Pajak tidak berpengaruh signifikan terhadap struktur modal pada perusahaan 
sektor industri barang konsumsi, property dan real estate. Selanjutnya, Darsono ( 2014) Meneliti Analisis Faktor-Faktor Yang Mempengaruhi Struktur Modal Pada Perusahaan Manufaktur Yang Terdaftar Di Bursa Efek Indonesia Tahun 2009 - 2010. Penelitian ini bertujuan untuk menganalisis ROA, struktur aktiva, pertumbuhan penjualan, dan ukuran perusahaan. Hasil penelitian adalah terdapat pengaruh negatif dan signifikan antara variabel profitabilitas yang diukur dengan menggunakan ROA terhadap struktur modal pada perusahaan manufaktur yang tercatat di BEI periode 2009-2010. Terdapat pengaruh positif dan signifikan antara variabel struktur aktiva, pertumbuhan penjualan dan ukuran perusahaan terhadap struktur modal pada perusahaan manufaktur yang tercatat di BEI periode 2009-2010.

Dari hasil penelitian terdahulu terdapat beberapa variabel yang berpengaruh terhadap struktur modal masih menunjukkan hasil yang berbeda bahkan bertentangan antara hasil penelitian yang satu dengan yang lainnnya. Hal inilah yang akan diangkat menjadi research gap dalam penelitian ini. Atas dasar research gap dari hasil penelitian sebelumnya serta perlunya perluasan penelitian yang didukung oleh teori-teori yang mendasari, maka penulis tertarik untuk meneliti beberapa variabel yang berpengaruh terhadap struktur modal yaitu profitabilitas, likuiditas, pertumbuhan penjualan, operating leverage, dan tangibility dengan sampel emiten sektor manufaktur yang terdaftar di Bursa Efek Indonesia dari tahun 2011-2014.

\section{KERANGKA PEMIKIRAN DAN HIPOTESIS}

Didalam bukunya Sartono (2010: 248) mengatakan, dengan laba ditahan yang besar, perusahaan akan lebih senang menggunakan laba ditahan sebelum menggunakan utang. Hal ini sesuai dengan pecking order theory yang menyatakan bahwa manajer lebih memilih menggunakan pembiayaan menggunakan pendanaan internal dibandingkan eksternal dengan urutan yang lebih dulu digunakan yaitu dari laba ditahan, kemudian utang, dan yang terakhir adalah penjualan saham baru. Tingkat profitabilitas dapat menunjukkan tingkat kemampuan sebuah perusahaan untuk mendanai kegiatan operasionalnya sendiri. Hal ini dikarenakan perusahaan dengan tingkat profitabilitas yang tinggi memiliki sumber dana internal yang besar, sehingga perusahaan dapat menggunakan dana internal tersebut dan tidak memerlukan hutang yang banyak. Dana internal tersebut diperoleh dari laba ditahan yang dihasilkan dari kegiatan operasional perusahaan. Perusahaan yang memiliki jumlah laba ditahan yang besar, akan lebih cenderung menggunakan laba ditahan terlebih dahulu daripada menggunakan hutang. 
Penelitian ini sejalan dengan penelitian yang dilakukan oleh Indrajaya, Herlina, dan Setiadi (2011: 19) yang menyatakan bahwa profitabilitas memiliki pengaruh parsial yang negatif dan signifikan terhadap penggunaan utang (leverage). Hasil ini menunjukkan bahwa semakin profitable perusahaan, maka perusahaan cenderung mengurangi proporsi utangnya. Berdasarkan uraian diatas dapat dirumuskan hipotesis sebagai berikut:

\section{$H_{1}$ : Profitabilitas berpengaruh negatif terhadap struktur modal pada perusahaan manufaktur yang terdaftar di Bursa Efek Indonesia (BEI) selama periode 2011- 2014}

Likuiditas perusahaan adalah kemampuan perusahaan dalam melunasi kewajiban jangka pendek yang telah jatuh tempo. Jika perusahaan banyak menggunakan aktiva lancar, maka perusahaan tersebut dapat menghasilkan aliran kas untuk membiayai aktivitas operasi dan investasi perusahaan. Aktiva lancar yang semakin besar menunjukkan bahwa perusahan berhasil melunasi hutang jangka pendeknya, sehingga dapat berakibat pada menurunnya proporsi hutang dalam struktur modal. Rasio likuiditas adalah rasio yang digunakan untuk mengukur kemampuan perusahaan didalam membayar hutang jangka pendek yang jatuh tempo dengan aktiva lancar yang dimiliki. Perusahaan dengan tingkat likuiditas tinggi, berarti perusahaan tersebut memiliki cukup banyak dana yang dapat digunakan untuk melunasi hutang jangka pendeknya. Sehingga semakin tinggi tingkat likuiditas, akan semakin rendah struktur modal yang digunakan. Hestuningrum (2012: 8) dalam penelitiannya menunjukkan bahwa likuiditas berpengaruh secara signifikan negatif terhadap struktur modal. Penelitian ini menunjukkan bahwa semakin tinggi likuiditas suatu perusahaan, maka strukur modalnya akan semakin rendah. Menurut Nugrahani (2012: 25) sisi pecking order, perusahaan cenderung lebih menyukai pendanaan internal. Hal tersebut dikarenakan kecilnya risiko yang ditanggung perusahaan apabila menggunakan pendanaan internal. Dengan besarnya kemampuan memenuhi kewajiban hutangnya, perusahaan hendaknya mengurangi risiko perusahaan dengan mengurangi hutang perusahaan tersebut. Berdasarkan uraian diatas dapat dirumuskan hipotesis sebagai berikut:

$\mathrm{H}_{2}$ : Likuiditas berpengaruh negatif terhadap struktur modal pada perusahaan manufaktur yang terdaftar di Bursa Efek Indonesia (BEI) selama periode 20112014 
Pertumbuhan penjualan menunjukkan kemampuan perusahaan dalam menjalankan usahanya yang tercermin dari perkembangan pertumbuhan penjualan. Bagi perusahaan dengan tingkat pertumbuhan penjualan dan laba yang lebih tinggi, kecenderungan penggunaan hutang sebagai sumber dana eksternal lebih besar dibandingkan dengan perusahaan-perusahaan dengan tingkat pertumbuhan penjualan yang tergolong rendah, sehingga struktur modal pada perusahaan dengan tingkat pertumbuhan penjualan tinggi akan menjadi besar. Haryanto (2012: 212) dalam penelitiannya menunjukkan pertumbuhan penjualan berpengaruh positif terhadap struktur modal. Artinya perusahaan dengan pertumbuhan penjualan yang tinggi, akan lebih berani mengambil modal eksternal untuk meningkatkan operasi perusahaan. Dengan penjualan yang semakin tinggi diharapkan perusahaan mampu meningkatkan produksinya, untuk itu diperlukan modal tambahan yang berasal dari luar perusahaan. Berdasarkan uraian diatas dapat dirumuskan hipotesis sebagai berikut:

\section{$\mathrm{H}_{3}$ : Pertumbuhan Penjualan berpengaruh positif terhadap struktur modal pada perusahaan manufaktur yang terdaftar di Bursa Efek Indonesia (BEI) selama periode 2011-2014}

Operating Leverage dapat diartikan sampai sejauh mana biaya tetap digunakan dalam operasi suatu perusahaan ( Brigham dan Houston, 2014: 160). Perusahaan lebih memilih struktur modal yang memiliki tingkat biaya modal yang rendah. Tingkat operating leverage yang tinggi memungkinkan perolehan keuntungan dari peningkatan volume penjualan. Operating Leverage merupakan faktor yang penting untuk dipertimbangkan dalam mengambil keputusan mengenai struktur modal perusahaan. Salah satu potensi pengaruh leverage operasional adalah perubahan dalam volume penjualan yang akan menghasilkan perubahan yang lebih dari proposional dalam laba atau rugi operasional. Ukuran kuantitatif dari sensitivitas laba operasional perusahaan atas perubahan dalam penjualan perusahaan disebut sebagai tingkat leverage operasional (degree of operating leverage/DOL). Junita, Nasir, dan Ilham (2014: 14) dalam penelitiannya mengatakan bahwa terdapat pengaruh antara Operating Leverage terhadap struktur modal. Tingkat leverage operasi yang tinggi memungkinkan perolehan keuntungan dari peningkatan volume penjualan. Haryanto (2012: 212) menyimpulkan hasil yang sama bahwa Degree of operating leverage (DOL) menunjukkan berpengaruh secara signifikan terhadap struktur modal. Rasio DOL yang memberikan suatu pemahaman tentang sensitivitas aliran kas operasi terhadap perubahan penjualan 
mempunyai pengaruh terhadap struktur modal perusahaan. Berdasarkan uraian diatas dapat dirumuskan hipotesis sebagai berikut:

\section{$\mathrm{H}_{4}$ : Operating Leverage berpengaruh positif terhadap struktur modal pada perusahaan manufaktur yang terdaftar di Bursa Efek Indonesia (BEI) selama periode 2011-2014}

Aset berwujud adalah sumber yang paling mudah diterima secara luas untuk dijadikan sebagai jaminan pinjaman atau hutang. Karena aset berwujud dapat berfungsi sebagai jaminan, sehingga dapat mengurangi risiko bagi pemberi pinjaman. Hal ini menandakan bahwa struktur aktiva dari suatu perusahaan memainkan peran penting dalam menentukan struktur modal perusahaan. Dalam penelitiannya, Umer (2014: 62) mengatakan bahwa terdapat hubungan positif yang signifikan antara tangibility dengan leverage suatu perusahaan yang diamati dari hasil regresi. Hal diatas pun dikemukakan oleh Alkhazaleh dan Almsafir (2015: 93) yang mengatakan bahwa variabel tangibility signifikan, dimana koefisien dari variabel tersebut positif. Hal ini menunjukkan bahwa proporsi yang lebih tinggi dari aset tetap pada total aset akan mengurangi masalah informasi asimetris dan perusahaan akan lebih banyak menggunakan hutang. Berdasarkan uraian diatas dapat dirumuskan hipotesis sebagai berikut:

$\mathrm{H}_{5}$ : Tangibility berpengaruh positif terhadap struktur modal pada perusahaan manufaktur yang terdaftar di Bursa Efek Indonesia (BEI) selama periode 20112014

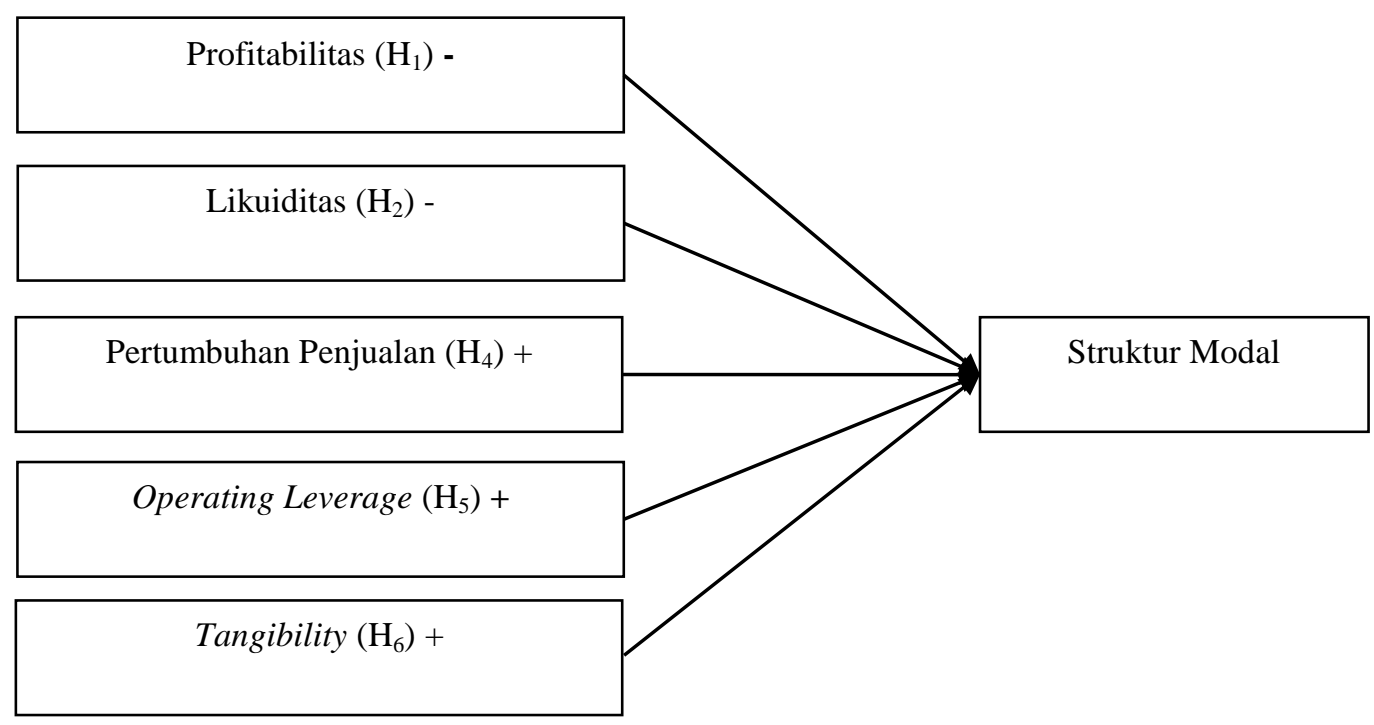




\section{GAMBAR I}

Model Penelitian

\section{METODE PENELITIAN}

Populasi dalam penelitian ini diperoleh dari laporan keuangan dan company profile perusahaan manufaktur yang terdaftar di Bursa Efek Indonesia (BEI), sesuai dengan pengklasifikasian Indonesian Capital Market Dictionary (ICMD) pada periode 2011-2014. Sampel penelitian ini sebanyak 41 perusahaan manufaktur. Teknik pengambilan sampel dalam penelitian ini menggunakan metode Purposive Sampling. Perusahaan yang dipilih adalah perusahaan yang sudah sesuai dengan kriteriakriteria yang telah ditentukan. Penelitian ini meneliti profitabilitas, likuiditas, pertumbuhan penjualan, operating leverage, dan tangibility yang diperoleh dari laporan keuangan dan company profile perusahaan manufaktur yang terdaftar di Bursa Efek Indonesia (BEI).

Metode analisis yang digunakan dalam penelitian ini adalah analisis regresi fixed effect dan uji hipotesis $t$-test. Untuk menguji pengaruh variabel bebas terhadap variabel terikat, penelitian ini menggunakan analisis regresi fixed effect, persamaannya adalah sebagai berikut:

$$
D A R_{i t}=a+\beta_{1} N P M+\beta_{2} C R_{i t}+\beta_{3} S G_{i t}+\beta_{4} D O L_{i t}+\beta_{5} T A N G_{i t}+e
$$

Dimana :

$D A R_{i t}=$ Total Debt to Total Assets pada periode $\mathrm{t}$

$N P M=$ Net Profit Margin perusahaan pada periode $\mathrm{t}$

$C R=$ current ratio (likuiditas) perusahaan pada periode $\mathrm{t}$

$S G=$ pertumbuhan penjualan perusahaan pada periode $\mathrm{t}$

$D O L=$ Degree of Leverage (leverage operasi) perusahaan pada periode $\mathrm{t}$

$T A N G=$ Tangibility (asset tetap) perusahaan pada periode $\mathrm{t}$

$a=$ Konstanta

$\beta_{1}, \beta_{2}, \beta_{3}, \beta_{4}, \beta_{5}=$ Koefisien Regresi

$e=$ Error, Variabel Pengganggu

\section{Operasionalisasi Variabel Penelitian}

\section{Variabel Dependen/Terikat (Y)}

Variabel dependen yang digunakan dalam penelitian ini adalah stuktur modal yang merupakan perbandingan atau perimbangan antara pendanaan jangka panjang 
dengan modal sendiri, dimana struktur modal ini akan diproksikan dengan Total Debt to Total Assets, yaitu rasio total hutang terhadap total aktiva yang dimiliki oleh perusahaan :

TDTA $=\frac{\text { Total Hutang }}{\text { Total Aset }}$

\section{Variabel Independen/Bebas (X)}

Penelitian ini menggunakan 5 variabel bebas yaitu Profitabilitas $\left(\mathrm{X}_{1}\right)$, Likuiditas $\left(\mathrm{X}_{2}\right)$, Pertumbuhan Penjualan $\left(\mathrm{X}_{3}\right)$, Operating Leverage $\left(\mathrm{X}_{4}\right)$, dan Tangibility $\left(\mathrm{X}_{5}\right)$.

a. Profitabilitas

Profitabilitas merupakan kemampuan perusahaan dalam memperoleh laba. Pengukuran profitabilitas pada penelitian ini mengacu pada penelitian terdahulu oleh Firnanti (2011) dan Hestuningrum (2012). Profitabilitas diproksikan dengan:

Net Profit Margin $=\frac{\text { Laba Bersih }}{\text { Penjualan }}$

b. Likuiditas

Likuiditas merupakan kemampuan perusahaan dalam memenuhi kewajiban jangka pendeknya. Pengukuran profitabilitas pada penelitian ini mengacu pada penelitian terdahulu oleh Hanafi (2012 : 37) dan Seftiane (2011). Likuiditas diproksikan dengan :

Current Ratio $=\frac{\text { Aktiva Lancar }}{\text { Hutang Lancar }}$

c. Pertumbuhan Penjualan

Pertumbuhan penjualan merupakan selisih antara penjualan pada tahun tertentu dikurangi dengan penjualan tahun sebelumnya dibagi dengan penjualan tahun sebelumnya. Pertumbuhan penjualan diproksikan dengan :

Sales Growth $=\frac{\text { Net Sales }(\mathrm{t})-\operatorname{Net} \text { Sales }(\mathrm{t}-1)}{\operatorname{Net} \text { Sales }(\mathrm{t}-1)}$

d. Operating Leverage

Leverage operasi merupakan kemampuan perusahaan dalam menggunakan biaya operasi tetap (fixed operating cost) untuk memperbesar pengaruh dari perubahan volume penjualan terhadap EBIT. Operating Leverage diproksikan dengan :

DOL $=\frac{\text { Persentase Perubahan EBIT }}{\text { Persentase Perubahan Penjualan }}$ 


\section{e. Tangibility}

Tangibility merupakan Besarnya aktiva yang dapat dijaminkan oleh perusahaan sebagai kolateral. Tangibility perusahaan diproksikan dengan :

$$
\text { Tangibility }=\frac{\text { Fixed Asset }}{\text { Total Asset }}
$$

\section{HASIL PENELITIAN DAN PEMBAHASAN}

Tabel 1

Statistik Deskriptif

\begin{tabular}{cccccc}
\hline & N & Mean & Max. & Min. & Std. Dev \\
\hline DAR (rasio) & 41 & 0.399491 & 0.753386 & 0.130592 & 0.143492 \\
NPM (rasio) & 41 & 0.097172 & 0.663368 & 0.000824 & 0.082616 \\
CR (rasio) & 41 & 2.381414 & 7.891744 & 0.403140 & 1.531235 \\
SG (rasio) & 41 & 0.137751 & 1.273150 & -0.349922 & 0.158914 \\
DOL (rasio) & 41 & 4.063777 & 242.9212 & -54.02783 & 22.62013 \\
TANG (rasio) & 41 & 0.389825 & 0.866768 & 0.090818 & 0.175334 \\
\hline Sumber: Data Diolah Oleh Peneliti menggunakan E-views 9 & &
\end{tabular}

\section{Statistik Deskriptif}

Berdasarkan Tabel 1, nilai rata-rata (mean) DAR perusahaan manufaktur di BEI adalah sebesar 0,3995 atau $39,95 \%$ dan standar deviasi sebesar 0,1435 atau $14,35 \%$ yang menunjukkan nilai rata-rata DAR lebih besar dibandingkan standar deviasinya sehingga mengindikasikan bahwa DAR pada perusahaan manufaktur memiliki variabilitas dan fluktuasi yang rendah. Rata-rata perusahaan manufaktur di Bursa Efek Indonesia memiliki total aktiva yang dibiayai oleh hutang sebesar 39,95\%, sedangkan sisanya yaitu $60,05 \%$ perusahaan memilih menggunakan pendanaan lainnya. Nilai DAR tertinggi dimiliki oleh PT. Alaska Industrindo Tbk pada tahun 2013 dikarenakan kenaikan pada total liabilitas sebesar 95,85\%. DAR terendah dimiliki oleh PT. Mandom Indonesia Tbk pada tahun 2012 yang mengindikasikan bahwa PT. Mandom Indonesia Tbk tidak terlalu memanfaatkan hutang jangka panjang maupun jangka pendek sebagai sumber pendanaan dalam kegiatan perusahaan.

Nilai rata-rata NPM perusahaan manufaktur di BEI adalah sebesar 0,0972 atau 9,72\% dengan standar deviasi sebesar 0,0826 atau 8,3\% yang menunjukkan nilai ratarata NPM lebih besar dibandingkan standar deviasinya sehingga mengindikasikan bahwa variabel Net Profit Margin (NPM) pada perusahaan manufaktur memiliki variabilitas dan fluktuasi yang rendah. Rata-rata perusahaan manufaktur di Bursa Efek Indonesia 
memiliki laba bersih yang dicapai sebesar 9,72\% dari volume penjualan. NPM tertinggi dimiliki oleh PT. Indofood Sukses Makmur Tbk pada tahun 2011 dikarenakan usaha yang terus berkembang dengan penjualan yang semakin meningkat dari tahun ke tahun sehingga menghasilkan laba bersih yang terus naik dari tahun sebelumnya sebesar Rp. 4,02 triliun menjadi Rp. 5,02 triliun di tahun 2011. NPM terendah dimiliki oleh PT. Sierad Produce Tbk pada tahun 2014, hal ini dikarenakan menurunnya tingkat penjualan perusahaan.

Pada variabel likuiditas, nilai rata-rata lebih besar dibandingkan dengan standar deviasinya. Nilai rata-rata dari CR adalah sebesar 2,3814 atau 238,1\% dan standar deviasi sebesar 1.5312 atau 153,1\%, sehingga mengindikasikan bahwa data variabel Current Ratio $(C R)$ pada perusahaan manufaktur memiliki variabilitas dan fluktuasi yang rendah. Setiap Rp. 1000 hutang lancar rata-rata perusahaan manufaktur di Bursa Efek Indonesia dijamin oleh Rp. 2.380 aktiva lancar. CR tertinggi dimiliki oleh PT. Delta Djakarta Tbk pada tahun 2013 dikarenakan pada tahun tersebut aset lancar yang dimiliki meningkat dari tahun sebelumnya dan liabilitas jangka pendek naik yang disebabkan oleh peningkatan hutang atas pembelian bahan baku produksi antara lain karena naiknya beban produksi dan seiring dengan tingkat persediaan bahan baku yang lebih tinggi pada akhir tahun berjalan. Peningkatan juga disebabkan oleh meningkatnya biaya yang harus di bayar untuk aktivitas promosi yang sedang berjalan serta meningkatnya biaya pensiun dan bonus kinerja. Hutang lain-lain juga meningkat terutama disebabkan oleh naiknya biaya distribusi dan penurunan hutang pajak. CR minimum dimiliki oleh PT. Nusantara Inti Corpora Tbk pada tahun 2013 karena pada tahun tersebut perusahaan yang bergerak dalam Bidang Usaha Investasi, Industri dan Perdagangan tersebut mengalami kenaikan aktiva lancar (current assets) yang juga diikuti oleh peningkatan hutang lancar (current liabilities).

Variabel SG yang ditunjukkan dalam tabel 1 memiliki nilai rata-rata lebih rendah dibandingkan dengan nilai standar deviasinya. Rata-rata SG adalah sebesar 0,1378 atau $13,78 \%$ sedangkan nilai standar deviasi sebesar 0,1589 atau $15,89 \%$, sehingga mengindikasikan bahwa data variabel Pertumbuhan Penjualan (SG) pada perusahaan manufaktur memiliki variabilitas dan fluktuasi yang tinggi. SG tertinggi dimiliki oleh PT. Multi Bintang Indonesia Tbk pada tahun 2013 karena pada tahun tersebut pendapatan MLBI meroket hingga 126,75\%. Sedangkan nilai SG terendah dimiliki oleh PT. Sierad Produce Tbk pada tahun 2014, Lababersih yang menunjukan kinerja 
Perseroan tahun 2014 anjilok 75,36\% bila dibandingkan dengan laba bersih pada tahun 2013.

Rata-rata DOL adalah sebesar 4,0638 atau 406,38\% dengan standar deviasi sebesar 22,6201 atau 2.262,01\% yang menunjukkan nilai rata-rata DOL lebih kecil dibandingkan dengan nilai standar deviasinya, sehingga mengindikasikan bahwa data variabel Operating Leverage (DOL) pada perusahaan manufaktur memiliki variabilitas dan fluktuasi yang tinggi. Setiap $1 \%$ pertumbuhan penjualan rata-rata perusahaan manufaktur di Bursa Efek Indonesia, laba sebelum bunga dan pajak yang dihasilkan adalah sebesar 406,38\%. Nilai DOL tertinggi dimiliki oleh PT. Lion Metal Works Tbk pada tahun 2013, sedangkan DOL terendah dimiliki oleh PT. Kabelindo Murni Tbk pada tahun 2013. Perusahaan ini memiliki DOL terendah dibandingkan perusahaan manufaktur lainnya disebabkan oleh pertumbuhan penjualan sebesar 1,2\%. Disamping itu laba sebelum pajak perusahaan ini mengalami penurunan dari Rp. 32 miliar pada tahun sebelumnya menjadi Rp. 10,7 miliar pada tahun 2013.

Nilai rata-rata Tangibility pada tabel 1 adalah sebesar 0,3898 atau 38,98\% dengan nilai standar deviasi sebesar 0,1753 atau 17,53\%, sehingga mengindikasikan bahwa data variabel Tangibility pada perusahaan manufaktur memiliki variabilitas dan fluktuasi yang rendah. Rata-rata perusahaan manufaktur di Bursa Efek Indonesia memiliki aktiva tetap sebesar $38,98 \%$ dari total aktivanya. Tangibility tertinggi dimiliki oleh PT. Holcim Indonesia Tbk pada tahun 2014, naiknya nilai seluruh aktiva selama setahun diakibatkan peningkatan aset tidak lancar, dalam hal ini tanah, pabrik dan peralatan untuk proyek Tuban, termasuk didalamnya jalur produksi pertama yang mulai dioperasikan pada tahun 2014. Nilai Tangibility terendah dimiliki oleh PT. Alaska Industrindo Tbk pada tahun 2013 disebabkan oleh aset tetap perusahaan hanya mengalami sedikit peningkatan berbanding dengan total asset yang mengalami peningkatan yang cukup besar. Sehingga perbandingan antara aset tetap dan total aset yang semakin jauh mengakibatkan nilai Tangibility perusahaan ini sangat kecil.

\section{Uji Normalitas}

Pada Gambar 1 nilai probabilitas Jacque Bera sebesar 0,067. Dengan demikian dapat disimpulkan bahwa pada uji normalitas, data berdistribusi normal karena memiliki nilai probabilitas Jacque Bera yang lebih besar dari 0,05. 


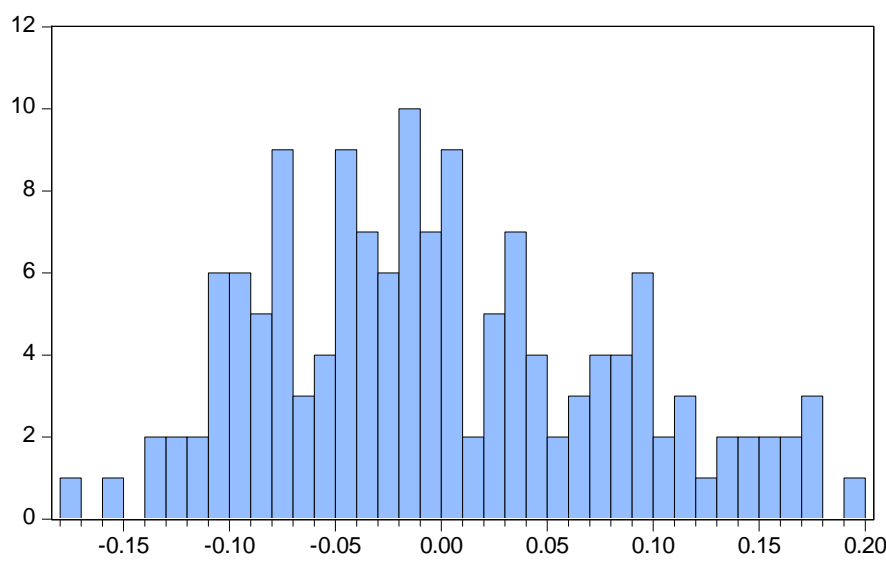

\begin{tabular}{|lc|}
\hline \multicolumn{2}{|l|}{ Series: Standardized Residuals } \\
Sample 2011 2014 \\
Observations & 144 \\
& \\
Mean & $1.20 \mathrm{e}-16$ \\
Median & -0.010571 \\
Maximum & 0.196908 \\
Minimum & -0.170265 \\
Std. Dev. & 0.081214 \\
Skewness & 0.381803 \\
Kurtosis & 2.438508 \\
& \\
Jarque-Bera & 5.390205 \\
Probability & 0.067535 \\
\hline
\end{tabular}

Gambar 2

Hasil Uji Normalitas Jarque-Bera

Sumber: Data diolah menggunakan EViews 9

\section{Uji Multikolinearitas}

Dari tabel II menunjukkan bahwa tidak ada koefisien korelasi antara variabel bebas yang melebihi 0,80 (rule of thumb), sehingga tidak ada multikolinearitas yang tinggi antara variabel bebasnya.

\section{Tabel II}

Hasil Uji Multikolinearitas

\begin{tabular}{ccccrrr}
\hline & DAR & NPM & \multicolumn{1}{c}{ CR } & \multicolumn{1}{c}{ SG } & \multicolumn{1}{c}{ DOL } & \multicolumn{1}{c}{ TANG } \\
\hline DAR & 1.000000 & -0.202287 & -0.801051 & 0.127988 & -0.170391 & 0.268852 \\
NPM & -0.202287 & 1.000000 & 0.134117 & 0.291260 & 0.083713 & 0.037299 \\
CR & -0.801051 & 0.134117 & 1.000000 & -0.121594 & 0.275690 & -0.502869 \\
SG & 0.127988 & 0.291260 & -0.121594 & 1.000000 & -0.095200 & 0.054955 \\
DOL & -0.170391 & 0.083713 & 0.275690 & -0.095200 & 1.000000 & -0.096950 \\
TANG & 0.268852 & 0.037299 & -0.502869 & 0.054955 & -0.096950 & 1.000000 \\
\multicolumn{7}{l}{ Sumber: Data diolah peneliti dengan menggunakan Eviews 9}
\end{tabular}

\section{Uji t}

Nachrowi dan Usman (2008) berpendapat bahwa uji-t merupakan suatu pengujian yang bertujuan untuk melihat apakah koefisien regresi signifikan atau tidak secara individu. Variabel bebas akan signifikan yaitu pada level 1\%, 5\% dan 10\%. Dengan demikian, ini menandakan bahwa hubungan variabel terikat dengan variabel bebas statistically significance. Uji t ini pada dasarnya menunjukan pengaruh satu variabel independen secara individual dalam menerangkan variasi variabel dependen. 
Nilai koefisien dari variabel Profitabilitas yang terdapat pada tabel III adalah sebesar 0,165010 mempunyai arti bahwa Profitabilitas berpengaruh negatif terhadap Struktur Modal. Nilai probability pada variabel Profitabilitas adalah 0,0201, nilai tersebut lebih kecil dari 0,05 yang berarti variabel Profitabilitas signifikan pada level 5\%. Sehingga hipotesis yang diterima adalah $\mathrm{H}_{1}$, bahwa Profitabilitas berpengaruh negatif signifikan terhadap Struktur Modal. Penelitian ini menemukan semakin tinggi NPM suatu perusahaan, maka perusahaan akan mengurangi proporsi hutangnya, dengan kata lain semakin besar NPM perusahaan semakin besar pula kemampuan perusahaan untuk membiayai kebutuhan investasinya dari sumber internal (seperti laba ditahan). Hasil penelitian ini mendukung pecking order theory. Perusahaan yang memiliki tingkat laba bersih atau keuntungan yang tinggi pada dasarnya tidak membutuhkan banyak pembiayaan dengan hutang karena laba yang dimilikinya mampu memenuhi sebagian besar kebutuhan perusahaan. Penelitian ini sejalan dengan penelitian yang dilakukan oleh Joni dan Lina (2010), Indrajaya, et al (2011), Hestuningrum (2012), dan Hossain (2015) yang juga menemukan bahwa Profitabilitas berpengaruh negatif signifikan terhadap Struktur Modal.

\section{Tabel III}

\section{Hasil Regresi Data Panel}

Dependent Variable: DAR

Method: Panel Least Squares

Date: 06/06/16 Time: 16:02

Sample: 20112014

Periods included: 4

Cross-sections included: 39

Total panel (unbalanced) observations: 144

\begin{tabular}{crrrr}
\hline \hline Variable & Coefficient & Std. Error & t-Statistic & Prob. \\
\hline \hline C & 0.540789 & 0.038330 & 14.10892 & 0.0000 \\
NPM & -0.165010 & 0.069878 & -2.361419 & 0.0201 \\
CR & -0.044006 & 0.006503 & -6.766889 & 0.0000 \\
SG & 0.051253 & 0.028540 & 1.795804 & 0.0755 \\
DOL & 0.000131 & 0.000207 & 0.635095 & 0.5268 \\
TANG & -0.071982 & 0.079045 & -0.910648 & 0.3647 \\
\hline \hline
\end{tabular}

Effects Specification

Cross-section fixed (dummy variables)

\begin{tabular}{lllr}
\hline \hline R-squared & 0.934355 & Mean dependent var & 0.399491 \\
Adjusted R-squared & 0.906127 & S.D. dependent var & 0.143492 \\
S.E. of regression & 0.043964 & Akaike info criterion & -3.164426 \\
Sum squared resid & 0.193283 & Schwarz criterion & -2.256983 \\
Log likelihood & 271.8387 & Hannan-Quinn criter. & -2.795692 \\
F-statistic & 33.10099 & Durbin-Watson stat & 1.682643 \\
Prob(F-statistic) & 0.000000 & &
\end{tabular}


Nilai koefisien dari variabel Likuiditas yang terdapat pada tabel III adalah sebesar 0,044006 yang mempunyai arti bahwa Likuiditas berpengaruh negatif terhadap Struktur Modal. Nilai probability pada variabel Likuiditas adalah 0,0000 nilai tersebut lebih kecil dari 0,01 yang berarti variabel Likuiditas signifikan pada level 1\%. Sehingga hipotesis yang diterima adalah $\mathrm{H}_{2}$, bahwa Likuiditas berpengaruh negatif dan signifikan terhadap Struktur Modal. Perusahaan yang likuid cenderung memiliki banyak aset lancar yang dapat digunakan dalam mendanai kebutuhannya, sehingga tingkat struktur modalnya akan lebih rendah. Hasil penelitian ini sesuai dengan penelitian yang dilakukan oleh Yuliati (2011) dan Hestuningrum (2012) yang juga menemukan bahwa Likuiditas berpengaruh negatif dan signifikan terhadap Struktur Modal.

Nilai koefisien dari variabel Pertumbuhan Penjualan yang terdapat pada tabel III adalah 0,051253 yang mempunyai arti bahwa Pertumbuhan Penjualan berpengaruh positif terhadap Struktur Modal. Nilai probability pada variabel Pertumbuhan Penjualan adalah 0,0755 nilai tersebut lebih kecil dari 0,1 yang berarti variabel Pertumbuhan Penjualan signifikan pada level $10 \%$. Sehingga hipotesis yang diterima adalah $\mathrm{H}_{3}$, bahwa Pertumbuhan Penjualan berpengaruh positif dan signifikan terhadap Struktur Modal. Perusahaan dengan tingkat pertumbuhan penjualan dan laba yang tinggi kecenderungan menggunakan hutang sebagai sumber dana eksternalnya lebih besar dibandingkan dengan perusahaan-perusahaan yang memiliki tingkat pertumbuhan penjualan yang tergolong rendah. Hasil penelitian ini sesuai dengan penelitian yang dilakukan oleh Ridloah (2010), Priyono (2011), Febriminanto (2012) yang juga menemukan bahwa Pertumbuhan Penjualan berpengaruh positif dan tidak signifikan terhadap Struktur Modal.

Nilai koefisien dari variabel Operating Leverage yang terdapat pada tabel III adalah 0,000131 yang mempunyai arti bahwa Operating Leverage berpengaruh positif terhadap Struktur Modal. Nilai probability pada variabel Operating Leverage adalah 0,5268, nilai tersebut lebih besar dari 0,05 . Sehingga hipotesis yang diterima adalah $\mathrm{H}_{0}$, bahwa Operating Leverage tidak signifikan terhadap Struktur Modal. Semakin tinggi tingkat leverage operasi perusahaan, maka akan berdampak pada semakin besar risiko usaha suatu perusahaan, dengan risiko usaha yang besar, maka kurang menarik minat kreditor untuk memberikan pinjaman karena kreditor cenderung memberikan pinjaman kepada perusahaan yang memiliki risiko usaha yang kecil. Meskipun ada kreditor yang akan memberikan pinjaman kepada 
perusahaan, namun kreditor akan menuntut tingkat pengembalian yang tinggi juga. Hasil penelitian ini sesuai dengan penelitian yang dilakukan oleh Ridloah (2010) yang juga menemukan bahwa Operating Leverage berpengaruh positif dan tidak signifikan terhadap Struktur Modal.

Nilai koefisien dari variabel Tangibility yang terdapat pada tabel III adalah sebesar 0,071982 yang mempunyai arti bahwa Tangibility berpengaruh negatif terhadap Struktur Modal. Nilai probability pada variabel Tangibility adalah 0,3647, nilai tersebut lebih besar dari 0,05. Sehingga hipotesis yang diterima adalah $\mathrm{H}_{0}$, bahwa Tangibility tidak signifikan terhadap Struktur Modal. Tidak adanya pengaruh antara Tangibility terhadap Struktur Modal dalam penelitian ini disebabkan oleh struktur aktiva perusahaan tidak dapat memprediksi nilai struktur modal karena perusahaan lebih cenderung menggunakan aktivanya untuk kegiatan operasional dan bukan digunakan untuk mengurangi resiko hutangnya. Dengan demikian, keputusan perusahaan yang lebih memilih menggunakan aktivanya untuk operasional, berdampak pada kurangnya penggunaan dana eksternal perusahaan, maka hal ini tidak merubah susunan Struktur Modal dari perusahaan. Hasil penelitian ini sesuai dengan penelitian yang dilakukan oleh Ridloah (2010), Seftianne (2011), yang juga menemukan bahwa Tangibility berpengaruh negatif dan tidak signifikan terhadap Struktur Modal.

\section{KESIMPULAN, IMPLIKASI DAN SARAN}

Penelitian ini menggunakan sampel sebanyak 41 perusahaan manufaktur yang terdaftar di BEI periode 2011 - 2014 dan menggunakan regresi data panel fixed effect untuk mengetahui pengaruh profitabilitas, likuiditas, pertumbuhan penjualan, operating leverage, dan tangibility terhadap struktur modal. Hasilnya menunjukkan bahwa profitabilitas dan likuiditas memiliki pengaruh negatif signifikan terhadap struktur modal. Variabel pertumbuhan penjualan memiliki pengaruh positif signifikan terhadap struktur modal. Sedangkan variabel operating leverage, dan tangibility tidak memiliki pengaruh signifikan terhadap struktur modal.

Diharapkan agar perusahaan-perusahaan manufaktur yang terdaftar di Bursa Efek Indonesia bisa mempertimbangkan variabel profitabilitas dalam memutuskan kebijakan struktur modal. Karena ketika NPM perusahaan meningkat, maka kebutuhannya dapat dibiayai oleh pendanaan internal, sehingga perusahaan tidak terlalu membutuhkan penggunaan dana dari eksternal. Juga mempertimbangkan variabel likuiditas dalam memutuskan kebijakan struktur modal. Karena ketika jumlah aset lancar yang dimiliki besar, maka dapat digunakan untuk mendanai kebutuhan perusahaan. Aktiva lancar selain 
persediaan dapat digunakan untuk menutup hutang jangka pendek, sehingga menurunkan proporsi hutang dalam struktur modal perusahaan. Bagi kreditur diharapkan agar penelitian ini dapat memberikan informasi dalam pengambilan keputusan yang tepat untuk memberikan pinjaman kepada perusahaan, dalam artian untuk pertimbangan tingkat kemampuan perusahaan dalam membayar kewajibannya dan keuntungan yang akan diberikan kepada kreditur.

Disarankan bagi peneliti selanjutnya hendaknya menambah faktor-faktor seperti risiko bisnis, posisi pajak, fleksibilitas keuangan, kepemilikan perusahaan, ukuran perusahaan, dan pertumbuhan perusahaan. Karena kemungkinan faktor-faktor tersebut memiliki pengaruh terhadap struktur modal. Selain itu memperpanjang periode penelitian untuk memperluas jumlah sampel juga memasukkan seluruh perusahaan yang terdaftar di Bursa Efek Indonesia agar lebih luas, tidak spesifik hanya untuk satu sektor perusahaan.

\section{DAFTAR PUSTAKA}

Alkhazaleh, Ayman Mansour dan Mahmoud Khalid Almsafir, "Does Asymmetry of Information Drive Banks' Capital Structure? Empirical Evidence from Jordan”, International Journal of Economics and Finance. 2015, Vol. 7, No. 3, pp. 89, 93.

Brigham, Eugene F \& Jole F Houston. Dasar-Dasar Manajemen Keuangan Jilid 2 Ed.11. Terjemahan Ali Akbar Yulianto. Jakarta : Salemba Empat, 2014.

Darsono, "Analisis Faktor-Faktor Yang Mempengaruhi Struktur Modal Pada Perusahaan Manufaktur Yang Terdaftar Di Bursa Efek Indonesia Tahun 2009 - 2010”. Jurnal Analitika. 2014, Vol. 1, No. 1, p. 10.

Firnanti, Friska. "Faktor-faktor yang Mempengaruhi Struktur Modal Perusahaan Manufaktur Di Bursa Efek Indonesia”, Jurnal Bisnis dan Akuntansi. 2011, Vol. 13, No. 2, p. 11.

Ghozali, H. Imam. Aplikasi Analisis Multivariate Dengan Program IBM SPSS19 Jilid 5 Ed. 5. Semarang : Badan Penerbit Undip, 2011.

Gujarati, Damodar N dan Dawn C. Porter. Dasar-dasar Ekonometrika. Edisi 5. Terjemahan Eugenia, Sita dan Carlos. Jakarta: Salemba Empat, 2013.

Haryanto, Sugeng. "Karakteristik Perusahaan Dan Risiko Bisnis Terhadap Struktur Modal Pada Perusahaan Otomotif", Jurnal Keuangan dan Perbankan. 2012, Vol.16, No.2, pp. 208, 212. 
Hestuningrum, R. Dian dan Darsono. "Pengaruh Karakteristik Perusahaan Terhadap Struktur Modal Perusahaan Pemanufakturan Yang Terdaftar Pada Bursa Efek Indonesia”, Jurnal Akuntansi. 2012, Vol. 1, No. 1, p. 8.

Horne, Wachowics, Jr. Prinsip-prinsip Manajemen Keuangan Jilid 1 Ed. 13. Terjemahan Dewi Fitriasari dan Deny Arnos Kwary. Jakarta : Salemba Empat, 2012.

Husnan, Suad dan Enny Pudjiastuti. Dasar-Dasar Manajemen Keuangan Jilid 1 Ed. 6. Yogyakarta : UPP STIM YKPN, 2012.

International Journal of Economics and Finance.

http://ccsenet.org/journal/index.php/ijef/search/titles. (Diakses pada tanggal 2

Oktober 2015)

Junita, Nasir, dan Ilham. "Pengaruh Profitabilitas, Pertumbuhan Aset, Operating Leverage, dan Ukuran Perusahaan Terhadap Struktur Modal Studi Empiris Pada Perusahaan Food and Beverages Yang Terdaftar di Bursa Efek Indonesia Periode 2010-2012”, Jurnal Keuangan. 2014, Vol. 1, No. 2, p. 14.

Kejawein, Bondan. Pengaruh Net Profit Margin, Likuiditas, Struktur Aktiva, Pertumbuhan Perusahaan, Ukuran Perusahaan, dan Return On Assets Terhadap Struktur Modal. Skripsi Sarjana (Tidak Diterbitkan). Yogyakarta : Fakultas Ekonomi Universitas Muhammadiyah Yogyakarta. 2015.

Liwang, Florencia Paramitha. "Pengaruh Pertumbuhan Penjualan, Struktur Aktiva, Rasio Hutang, Profitabilitas, Ukuran Perusahaan, dan Likuiditas Terhadap Struktur Modal", Jurnal Semantik. 2011, p. 9.

Mamduh, M. Hanafi. Manajemen Keuangan Jilid 1 Ed. 1. Yogyakarta : BPFE, 2008.

Martono dan Agus Harjito. Manajemen Keuangan. Yogyakarta : Ekonisia, 2010.

Nachrowi, Nachrowi Djalal dan Hardius Usman. Penggunaan Teknik Ekonometri Ed. Revisi. Jakarta : PT RajaGrafindo Persada, 2008.

Nugrahani, Sarsa Meta. Analisis Pengaruh Profitabilitas, Likuiditas, Pertumbuhan Penjualan, Ukuran Perusahaan, dan Manajerial Ownership Terhadap Struktur Modal Perusahaan (Pada perusahaan manufaktur yang terdaftar di BEI). Skripsi Sarjana (Tidak Diterbitkan). Semarang : Fakultas Ekonomi dan Bisnis Universitas Diponegoro. 2012.

Priyono, Achmad Agus. "Faktor-Faktor Yang Mempengaruhi Struktur Modal Pada Perusahaan Manufaktur Yang Terdaftar Di BEI", Jurnal Bisnis dan Akuntansi. 2011, p. 21. 
Riyanto, Bambang. Dasar-Dasar Pembelanjaan Perusahaan Jilid 1 Ed. 4. Yogyakarta : BPFE, 2011.

S. Munawir. Analisa Laporan Keuangan Jilid 15 Ed. 4. Yogyakarta : Liberty, 2010.

Sartono, R. Agus. Manajemen Keuangan Teori dan Aplikasi Jilid 1 Ed. 4. Yogyakarta : BPFE, 2010.

Setiana, Esa. “Analisis Faktor-Faktor Yang Mempengaruhi Struktur Modal Pada Perusahaan Manufaktur Yang Listing Di Bursa Efek Indonesia (BEI)", Jurnal Keuangan dan Bisnis. 2012, Vol. 4, No. 3, p. 11.

Setiyawan, Iwan. Pengaruh Dividen, Profitabilitas, Ukuran Perusahaan, Risiko Bisnis dan Pajak Terhadap Struktur Modal. Surakarta: Fakultas Ekonomi dan Bisnis, 2014.

Umer, Usman Muhammed. "Determinants of Capital Structure: Empirical Evidence from LargeTaxpayer Share Companies in Ethiopia", International Journal of Economics and Finance. 2014, Vol. 6, No. 1, p. 62.

Widarjono, Agus. Ekonometrika Pengantar dan Aplikasi Jilid 1 Ed. 4. Yogyakarta : UPP STIM YKPN, 2012.

Winarno, Wing Wahyu. Analisis Ekonometrika dan Statistika dengan EViews Jilid 1 Ed. 3. Yogyakarta : UPP YKPN, 2011.

Yuliati, Sri. "Pengujian Pecking Order Theory : Analisis Faktor-Faktor Yang Mempengaruhi Struktur Modal Industri Manufaktur Di BEI Periode Setelah Krisis Moneter", Jurnal Politeknosains. 2011, Vol. 10, No. 1, p. 14. 